(1)

\title{
Economic Interactions among Stock Market Performance and Macroeconomic Variables with Mediating Role of Gold Prices Volatilities: An Evidence from Pakistan
}

\author{
Rukhsana Rasheed ${ }^{a}$, Mazhar Nadeem Ishaq ${ }^{b}$, Rabia Anwar $^{c}$, Mehwish Shahid $^{\mathrm{d}}$ \\ ${ }^{a}$ Assistant Professor, The Government Sadiq College Women University Bahawalpur, Pakistan \\ Email: rukhsana.rasheed@gscwu.edu.pk \\ $\mathrm{b}$ The Islamia University of Bahawalpur, Pakistan \\ ${ }^{\mathrm{c}}$ The Government Sadiq College Women University Bahawalpur, Pakistan \\ d The Government Sadiq College Women University Bahawalpur, Pakistan
}

\begin{tabular}{|c|c|}
\hline ARTICLE DETAILS & ABSTRACT \\
\hline $\begin{array}{l}\text { History: } \\
\text { Accepted } 15 \text { August } 2021 \\
\text { Available Online September } 2021\end{array}$ & $\begin{array}{l}\text { In all emerging economies, one of the most challenging issues for } \\
\text { investors is the multifaceted inter-relationship between volatility of gold } \\
\text { prices and stock market index. During the COVID-19 sub-periods, gold } \\
\text { has shown a strong hedging behavior against stock market performance. }\end{array}$ \\
\hline $\begin{array}{l}\text { Keywords: } \\
\text { Stock Market, Macroeconomic } \\
\text { Variables, Gold Prices, KSE-1Oo } \\
\text { Index }\end{array}$ & $\begin{array}{l}\text { The main objective of this study was to quantify the long-run } \\
\text { relationship among multiple independent macroeconomic variables } \\
\text { (predictors) on stock market index (response variable) using the } \\
\text { volatilities of gold prices as a mediator factor. This study applied the } \\
\text { descriptive statistics, correlation, t-test and OLS multiple regression }\end{array}$ \\
\hline $\begin{array}{l}\text { JEL Classification: } \\
M 21, G 17, E_{37}\end{array}$ & $\begin{array}{l}\text { Model. The specific data comprised of period 2011-2020 regarding the } \\
\text { fluctuations in gold prices, exchange rate, interest rate, inflation rate } \\
\text { and performance of stock market index has been utilized. The statistical }\end{array}$ \\
\hline DOI: $10.47067 /$ reads.v7i3.384 & $\begin{array}{l}\text { outputs of models showed that exchange rate (Dollar to PKR) was } \\
\text { positively affecting the performance of Karachi Stock Exchange (KSE)- } \\
100 \text { Index, whereas inflation rate and interest rate were negatively } \\
\text { affecting the overall performance of KSE1oo index. The findings of this } \\
\text { study suggested that to achieve better performance of stock market, } \\
\text { relatively low interest rate and inflation rate contribute a significant } \\
\text { role. However, to increase the generalization capabilities of this study } \\
\text { the impact of mentioned macroeconomic variables in other sectors like } \\
\text { industrial production, oil \& gas and energy sectors with wider time span } \\
\text { can be more helpful. }\end{array}$ \\
\hline
\end{tabular}

(C) 2021 The authors. Published by SPCRD Global Publishing. This is an open access article under the Creative Commons Attribution-

NonCommercial 4.0

Corresponding author's email address: rukhsana.rasheed@gscwu.edu.pk

\section{Introduction}

A stock market refers to public markets where brokers trade in corporate shares and other securities. The stock market is also known as equity market or share market that facilitates the buying 


\section{Review of Economics and Development Studies, Vol. 7 (3) 2021, 383-394}

and selling of publicly held companies' stock shares (Hiransha et al.2018).Financial markets are well recognized and vital tools for economic growth because it mobilize the idle savings in the economy and convert them into productive and useful capital. Usually growth of financial markets is stimulated when an economy generates more surplus resources (Pan et al. 2018).

The Pakistan Stock Exchange market (abbreviated as PSX) is a stock market with trading floors in three cities i.e. Karachi, Islamabad and Lahore. Initially, these stock exchange markets i.e. the Karachi Stock Exchange (KSE), Lahore Stock Exchange and the Islamabad Stock Exchange were established in years 1947, 1970, 1992 respectively. In 2016, however these stock exchanges market were merged into the PSX. There are about 540 companies listed in Pakistan Stock Exchange and total market capitalization wasUS $\$ 52$ billion PXS uses modern electronic trading system which is known as Karachi Automated Trading System (KATS), which gives the advantages to stock market to get their work done speedily and with minimum transactions cost (Pakistan stock exchange limited, 2020).

Gold being precious metal remained a symbol of wealth and prosperity. Like money, gold serves as medium of exchange and store of value. Currently too gold is still being used as an investment tool. (Hashim et al. 2017).The International financial institutions and central banks retained a huge quantity of gold for economic security and diversification. Kaufmann and Winters (1989) concluded that during crises times in market, investment in gold helps to diversify the increasing risks. The cognizance of gold price volatility is quiet essential for investors to guess the share valuations, take hedging decisions and to get a better outlook of whole economy (Tully and Lucey, 2007). Gold is a close substitution of stock share and changes in its prices has great impact on performance of stock exchange markets and inflation (Gokmenoglu \& Fazlollahi, 2015).

Rate of exchange is the purchasing power of one currency against another currency. The exchange rate is extremely important for international trade and overall economic development. Exchange rate is one of the key instrument of monetary policy. Positive currency exchange rate has a good impact on the economy of country (Kumar, 2011; \& Kakhani, 2012).

Inflation indicates a sustained increase in overall price level and this phenomenon decrease the purchasing power of consumers. Saleem et al. (2013) studied the long-run relationship between stock market returns and inflation rate. Their research proved stock market returns are affected by inflation rate. The investors in stock market keep a close eye on inflation rate to analyse the factor of risk because inflation affect their profit margin (Geske and Roll, 1983).

Interest rate is defined as the amount of money a lender charge to a debtor for the use of an asset or capital. Institutions levied higher interest rate if the debtor is considered of high risk. Alam and Salah Uddin (2009) found that stock prices and interest rate are negatively inter-linked. Chong \& Goh (2005) explored that growth in the economy is determined by the fluctuations in stock prices. When prices of stock rises upward it point out the improvement in the economy of every country, whereas on the other hand, negative growth in the economy of any country results the decline in stock prices. The study results suggested that macroeconomic activities strongly influence the growth and movements of stock prices. This determines that prices of the market can be taken from the future market accomplishments of the firm. The performance of stock market is significantly influenced by the macroeconomic variables such as foreign currency reserve, exchange rate and interest rate (Ullah and Islam, 2017).

The volatilities in gold prices and fluctuations in macroeconomics indicators i.e. exchange rate, 


\section{Review of Economics and Development Studies, Vol. 7 (3) 2021, 383-394}

inflation rate and interest rate have extensive direct and indirect impacts on financial activities, aggregate consumption, industrial production and investment in all other sectors of Pakistan economy. The volatility in the prices of oil, gold and foreign exchange may affect one another and make it difficult for the analysis to forecast the business environment (Ali et al. 2021). In Pakistan's culture and society, gold holds its importance as a potential investment for the common man because gold retained a safe investment option as compared to the real estate and stock market (Qasim et al. 2021).

Although in general, a plethora of research studies have been conducted to analyze the interlinks among volatilities of macroeconomic variables and stock market performance. Many studies have postulated that stock market and macroeconomic variables do have significant relationship while several studies found inconclusive interactions at best. However, most of these studies were conducted in developed countries but rarely carried out in developing countries with a focus to quantify stock market performance in relation to continuous variations of macroeconomic variables. On this background, this study attempt to assess the impact of intervallic variations carried out in some macroeconomic variables such as exchange rate, interest rate and inflation rate has been estimated on the performance of stock market using the volatilities of gold prices as mediator factor.

\section{Literature Review}

The economic interactions between stock market performance and macroeconomic variables have been widely studied through various comprehensive studies like like Engle and Rangel, 2005; Hull, 2012; Olugbenga, 2012; Smart et al., 2014; Ali, 2014; Al-Naif, 2017; Adebowale, 2018; Bhuiyan, 2020 etc. In all referred studies, theoretically the change in macroeconomic variables such as foreign currency reserve, interest rate, money supply and rate of exchange will lead an visible impact on stock market index.

Henry (2000) explored that growth in the economy is determined by the fluctuations in stock prices. When prices of stock move upward, it indicates an improvement in economic growth of a country. This study found that macroeconomic activities have significant impact on economic growth and stock prices. According to the findings of Elumilade et al. (2006) to ensure long-term assurances of the economy in real capital, stock market plays an important role. Lee \& Wang (2012) recognized that relationship between currency exchange rate and returns of stocks vary from one country to other.

Beckmann and Czudaj (2012) examined the relationship between gold prices and its ability to hedge against inflation. They analyzed the data from 1970 to 2011 of world major economies, USA, UK, European countries and Japan. They used Markov-switching vector error correction model (MS-VECM) and discern a difference between long-run and short-run time varying dynamics. The study concluded that gold in long-run is to some extent is able to hedge against inflation and this propensity was stronger for USA and UK but equated for Japan and European countries. The study also revealed that time horizon is a crucial thing for investors for the usefulness of gold as an inflation hedge.

Omag(2012) conducted a study in Turkey using the data of gold prices and selected indicators from January 2002 to December 2011. Regression model was applied as statistical tool to draw the inferences. The study concluded that gold prices are positively influenced by inflation rate and nominal interest rate. The results also exhibited a positive correlation between prices of gold and Istanbul Stock Exchange 100 index.

Bilal et al. (2013) conducted a comparative study between Karachi and Bombay stock markets. The data relating to prices of gold and stock shares had been used to quantify the long-run relationship 
Review of Economics and Development Studies, Vol. 7 (3) 2021, 383-394

between stock market performance and gold prices. Applied statistical tools such as Unit Root Augmented Dickey Fuller (ADF) test, Phillips-Perron, Johnson Co-integration and Granger's Causality tests had been used. The inferences of study were that no co-integration between series existed and neutral effect between prices of stock shares and gold was disclosed by causality test.

Shahbaz et al. (2014) studied the reliable hedging of gold for Pakistan. By using ARDL bounds test approach and data from 1997 to 2011; they also report that gold performed as an active hedge contrary to rate of inflation both in the long-run relationship and in the short-run relationship. Bialkowski et al. (2014) also investigated whether an asset bubble exists in the gold and stock market. They estimated basic value of gold by using several econometric models and apply an Augmented Dickey-Fuller (ADF) experiment.

Gosh (2016) examined the central banks' portfolio for foreign exchange reserve and gold demand. A panel data of over 100 nations ranging from 1998-2014 was used in this study. The results showed that several factors such as monetary policy, high exchange rate and inflation properties of an economy significantly increase the demand for gold holding. While Kumar, 2017) studied the long-run relationship between gold prices and inflation in Indian context. He suggested that gold prices should not be used as a hope to manage the inflation in country.

Chandrashekar et al. (2018) probed the pattern of stock prices and macroeconomic variables using the monthly data from 2000 to 2018 across the panel of Brazil and India. Data analysis was carried out through panel econometric techniques. The results of this study proved that unidirectional causality and a long-run relationship among proposed variables exist. It was also found that economic development is significantly influenced by GDP, inflation rate, exchange rate and stock prices.

John (2019) carried out a study in Nigeria to examine stock market performance and effects of money supply, annual interest rate and inflation. He used annual data series spanning 1981 to 2016. Augmented Dickey-Fuller (ADF) test and Ordinary Least Square (OLS) regression were used for stationary check and data analysis respectively. Long-run relationship between stock market performance and selected variables was proved through the results of co-integration test. Money supply had positive and significant impact while interest rate revealed a negative impact on stock market performance. Overall this study concluded that in Nigeria context, money supply and inflation are two true macroeconomic variables that influence stock market.

Alam (2020) conducted a comprehensive study to examine the stock market and its relationship with fiscal deficit, exchange rate, FDI, GDP ratio and real interest rate. Annual data set spanning 1993 to 2019 was collected from five South Asian countries i.e. Nepal, India, Bangladesh, Sri Lanka and Pakistan. Autocorrelation test, Heteroscedasticity test, unit root test and Hausman test were used. Results of study revealed that cause and effect relationship exist between GDP growth rate and stock market index.

Notable research studies have been carried out to explore the association of stock markets with various factors in different contexts and produced a blend of conclusions. However, this study has been carried in perspective of mediating role of gold prices volatilities on the linkage of macroeconomic variables and stock market performance

\section{Research Methodology}

\subsection{Nature of Study and Data Description}

Research design for this study was explanatory in nature. The inter-relationship between stock 
Review of Economics and Development Studies, Vol. 7 (3) 2021, 383-394

exchange market and volatilities in gold prices has been explained. The KSE-100 is an index of Pakistan Stock Exchange and this indicator represents weighted index of about top 100 companies with 90\% of capitalization in stock market. KSE-100 index acts as a standard for investor to relate stock prices with investment appraisal. For the measurement of stock exchange market performance, KSE-10o index has been taken as proxy variable. Three crucial macroeconomic variables such as exchange rate, inflation rate and real interest rate have been selected as independent variables while fluctuating gold prices has been taken as mediating variable affecting the linkage between above three mentioned macroeconomic variables and performance of stock market.

\subsection{Data Collection}

This paper aims to analyze how the stock market performance is influenced by selected three macroeconomic variables i.e. exchange rate, inflation rate, real interest rate and gold price per tola (11.663 grams). The data used in this paper was time series and it was collected from secondary sources that contains observations of macroeconomic variables over the period from 2011 to 2020. The defined stock market index figures were collected from Pakistan Stock Exchange website and data about the macroeconomic variables were taken from the websites of reliable national as well international organizations like, Pakistan Bureau of Statistics, State Bank of Pakistan, World Bank, Trading Economies etc.

\subsection{Data Validation Tools}

\subsubsection{Descriptive statistics}

Descriptive statistics have been used to examine the overall summary of variables; rate of inflation rate, exchange rate (Dollar to PKR), interest rate, prices of gold and KSE-10o. Frequency distribution tabulation and percentage were calculated to summarize the data and central tendency measurements like mean, median, maximum, minimum etc.

\subsubsection{Coefficient of correlation}

Coefficient of correlation was used to check the relation among the variables; rate of inflation rate, exchange rate (Dollar to PKR), interest rate, prices of gold and KSE-100 as well as to assess the research hypothesis for their acceptance or rejection. The presence of relationship between two variables is primarily determined by a value that can range from -1 to +1 . If value is o- reveals no correlation, between 0.2 to 0.4 -weak correlations, 0.6 to 0.8 -reveals strong correlation between the variables.

\subsection{Econometric Model Specification}

As multivariate or multiple regression model is an appropriate statistical technique to assess the relationship between multiple independent variables (predictors) and their impact on dependent variable (response variable). Therefore in this study, a regression model have been developed to test the significance of relationship between stock market performance and selected macroeconomic variables.

The model analyzed the impact of gold price volatilities on the relationship between rate of inflation and KSE 100 index, on relation of exchange rate and KSE 100 and on relation of interest rate and KSE 100. The mediated effect of independent variables (Xn) to dependent variable (SMP) can be quantified as the product of the regression coefficient relating Xn to SMP. 


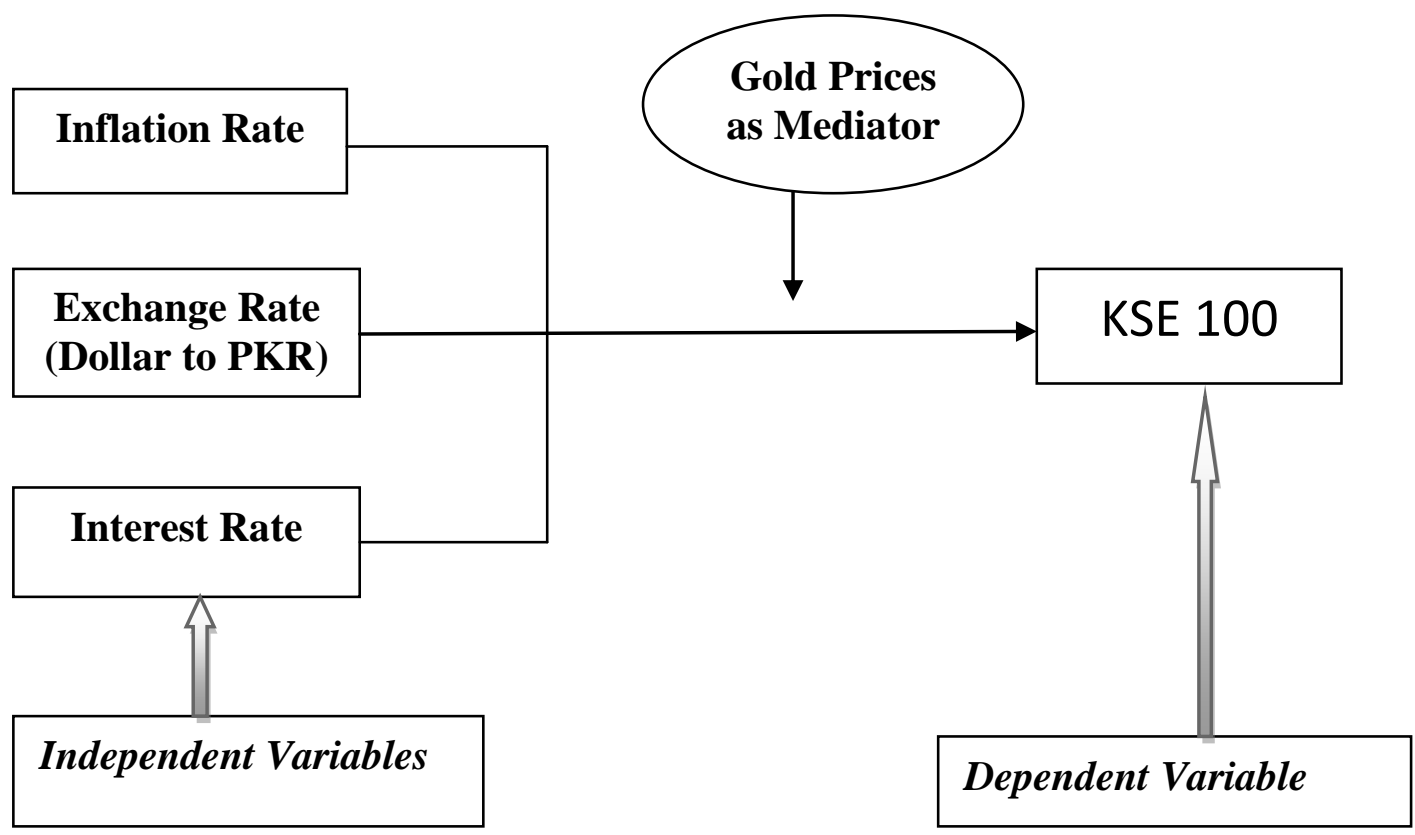

Figure 1: Mediating Gold Price Variable and Stock Market

To establish a functional relationship between selected macroeconomic variables and stock market performance, following model has been developed as:

\section{SMP = f (Exchange Rate, Interest Rate, Inflation and Gold Prices)}

Where, SMP in this study is the stock market performance because it contains 540 large companies picked based on market capitalization and high liquidity from a vast number of industries. To test a variable as moderator in regression, an interaction factors have been created by multiplying independent variables i.e. exchange rate, interest rate, and inflation rate with moderator variable i.e. gold prices. Multiple regression was then run alongwith the selected independent variables, moderator and interaction factors simultaneously in the model.

The following econometric equation would yield a better economic interpretation of given variables:

Where:

$$
\hat{Y}=\alpha+\beta_{1} X_{1 i}+\beta_{2} X_{2 i}+\beta_{3} X_{3 i}+\beta_{4} X_{4 t}+\mu
$$

$\hat{Y}=$ KSE-100 index

$\mathrm{X}_{1 \mathrm{i}}=$ Exchange rate (Dollar to PKR)

$\mathrm{X}_{2 \mathrm{i}}=$ Inflation rate

$\mathrm{X}_{3 \mathrm{i}}=$ Interest rate

$\mathrm{X}_{4 \mathrm{t}}=$ Gold price

$\alpha=$ Constant

$\beta=$ Regression Coefficient

$\mu=$ Error term 


\section{Research Hypothesis}

Table 1: The following individual hypothesis for each model is listed:

\begin{tabular}{|l|l|l|}
\hline Independent Variables & Model-1 Hypothesis & Model-2 Hypothesis \\
\hline Exchange rate & $\begin{array}{l}\text { (H1): There is a positive } \\
\text { relationship between exchange } \\
\text { rate (Dollar to PKR) and } \\
\text { KSE100. }\end{array}$ & $\begin{array}{l}\text { (H5): There is a positive impact of } \\
\text { gold prices fluctuations on the } \\
\text { association between exchange rate } \\
\text { (Dollar to PKR) and KSE100. }\end{array}$ \\
\hline Inflation Rate & $\begin{array}{l}\text { (H2): There is a positive } \\
\text { relationship between inflation } \\
\text { rate and KSE10o. }\end{array}$ & $\begin{array}{l}\text { (H4): There is a positive impact of } \\
\text { gold prices fluctuations on the } \\
\text { relationship between inflation rate } \\
\text { and KSE10o. }\end{array}$ \\
\hline Real interest rate & $\begin{array}{l}\text { (H3): There is a positive } \\
\text { relationship between real } \\
\text { interest rate and KSE100. }\end{array}$ & $\begin{array}{l}\text { (H6): There is a positive impact of } \\
\text { gold prices fluctuations on the } \\
\text { relationship among real interest rate } \\
\text { and KSE100 }\end{array}$ \\
\hline
\end{tabular}

\section{Results and Discussion}

The relationship among exchange, inflation, and interest rates on stock market performance has been tested through various statistical tools. The empirical findings are illustrated below.

\subsection{Descriptive Statistics}

As the descriptive statistics reveal a summarized outlook of given data. In this study, descriptive statistics has been bifurcated into: (i) measure of dispersion that exhibit the standard of deviation, the variance, maximum and minimum, the kurtosis and skewness; (ii) measures of central involving the mean, median and mode.

Table 1: Descriptive Statistics

\begin{tabular}{|l|c|c|c|c|c|}
\hline & KSE100 Index & Exchange rate & Inflation rate & Interest rate & Gold price \\
\hline Mean & 37614.23 & 110.3469 & 4.538667 & 7.560000 & 55993.45 \\
\hline Median & 38008.01 & 102.7413 & 3.965000 & 6.515000 & 51552.23 \\
\hline Maximum & 51191.65 & 161.8366 & 9.180000 & 10.52000 & 130320.25 \\
\hline Minimum & 26112.19 & 85.1722 & 1.320000 & 6.210000 & 47352.2 \\
\hline Std. Dev. & 6631.828 & 24.7863 & 1.879884 & 1.606239 & 33244.66 \\
\hline Skewness & 0.164281 & 1.3186 & 0.776265 & 0.837464 & 1.183343 \\
\hline Kurtosis & 1.989377 & 0.8867 & 2.897032 & 1.990470 & 3.643250 \\
\hline & & & & & \\
\hline Jarque-Bera & 2.823283 & 76.39899 & 6.052378 & 9.561330 & 20.75369 \\
\hline Probability & 0.243743 & 0.000000 & 0.048500 & 0.008390 & 0.000031 \\
\hline & & & & & \\
\hline Sum & 2256854. & 6451.348 & 272.3200 & 453.6000 & 778713.6 \\
\hline Sum Sq. Dev. & $2.59 \mathrm{E}+09$ & 4303.997 & 208.5039 & 152.2202 & $1.12 \mathrm{E}+10$ \\
\hline & & & & & 120 \\
\hline Observations & 120 & 120 & 120 & 120 & \\
\hline
\end{tabular}

Source: Authors' data analysis results, 2021 
Review of Economics and Development Studies, Vol. 7 (3) 2021, 383-394

Table 1 depicted that the mean value of KSE-100 index, exchange, inflation, interest rates and gold prices are; 37614.23, 110.34, 4.53, 7.56, 55993.45 respectively. Likewise the values of median for KSE100, exchange rate, inflation rate, interest rates and gold prices are given in Table 4.1 as 38008.01, $102.74,3.96,6.51$, and 51552.23 respectively. If value of mean is greater than median than it shows normality, because median is more robust with respect to outliers. So when outliers are expected in data, then median is the better choice.

As the skewness is a measure of symmetry and its distribution range lies from -1 to +1 . If distribution looks same towards the left and right of center point, it is symmetric distribution. Normal distribution has zero skewness. When tail is longer on the right side of distribution, it will yield positive skewness. But when tail is longer on the left side of distribution, it gives negative skewness. Usually to have a symmetric data, skewness should be near to zero.

The value skewness for KSE-100, inflation rate, exchange rate, real interest rate and gold price is $0.1643,1.3186,2.0506,0.8375$, and 1.18334 respectively. The skewness of KSE10o, inflation and interest rates are within the range, whereas the skewness of exchange rate and gold price exceeded the value of skewness distribution range. This exceed might be due to volatilities in the dollar exchange rate and abrupt fluctuations in gold prices which are stimulated because of political instability and some other related factors in recent years of Pakistan.

Kurtosis is measure of outliers present in data distribution. Kurtosis showed that whether data is heavy-tailed or light-tailed relative to normal distribution. When there is high value of kurtosis it indicates that data has heavy tails or have so many outliers which may be because of wrong data entry or other things. Contrary to it low kurtosis in data set showed that data has light tail or lack of outliers. The value of kurtosis for KSE-10o index, exchange rate, inflation rate, real interest rate and gold prices is $1.9905,0.8867,2.8970$, and 3.6432 respectively. The kurtosis value of KSE-100 index, exchange rate and interest rate are within the acceptable range of +2 and -2 while the kurtosis value of inflation and gold prices exceeded than normal distribution range of kurtosis. This may be due to political instability and fluctuations in various micro and macroeconomic variables in Pakistan.

\subsection{Correlation Analysis}

Correlation test is used to check the relationship and test research hypothesis formulated among selected macroeconomic variables and stock market performance. The outcomes are mentioned in Table 2.

\section{Table 2: Results of Correlation Analysis}

\begin{tabular}{|c|c|c|c|c|c|}
\hline & Exchange rate & Gold price & Inflation rate & Interest rate & KSE10o index \\
\hline Exchange rate & 1 & 0.8585 & 0.1398 & 0.0133 & 0.3510 \\
\hline Gold price & 0.8585 & 1 & 0.3338 & 0.0656 & 0.3818 \\
\hline Inflation rate & 0.1398 & 0.3338 & 1 & 0.7276 & -0.3189 \\
\hline Interest rate & 0.0133 & 0.0656 & 0.7276 & 1 & -0.6735 \\
\hline KSE10o index & 0.3510 & -0.3818 & -0.3189 & -0.6735 & 1 \\
\hline
\end{tabular}

Source: Authors' data analysis results, 2021

Hypothesis 1: The first hypothesis was that there is a positive association between rate of exchange (Dollar to PKR) and KSE10o and afterwards values exhibited that there is a positive association between them i.e. (0.3510) 
Hypothesis 2: The second hypothesis was that there is a positive relationship among the rate of inflation and KSE10o. But after analysis as stated in the above correlation table, there is a negative relation between rate of inflation and KSE10o i.e. (-0.3189)

Hypothesis 3:The third hypothesis was that there is a positive link between rate of interest and KSE10o but the outcomes described that there is a negative link between them just like rate of inflation and KSE10o i.e. (-o.6735)

Hypothesis 4: The fourth hypothesis was that there is a positive influence of fluctuations in the price of gold on the relationship between rate of exchange (Dollar to PKR) and KSE10o and that hypothesis got accepted after the detailed analysis of the data

Hypothesis 5: The fifth hypothesis was that there is a positive effect of fluctuations on the price of gold on the relationship between rate of inflation and KSE10o index and the analysis did displayed that there is a positive effect of gold price fluctuations on the rate of inflation and KSE1Oo.

Hypothesis 6: The sixth hypothesis was that there is positive influence of fluctuations in the price of gold on the association between rate of interest and KSE1Oo and the data does support this hypothesis also.

Table 3: Decisions of formulated Hypothesis

\begin{tabular}{|c|c|c|}
\hline Serial \# & Research Hypothesis & Decision \\
\hline $\mathbf{1}$ & $\begin{array}{l}\text { There is a positive connection between rate of Exchange (Dollar } \\
\text { to PKR) and KSE1Oo. }\end{array}$ & Accepted \\
\hline 2 & $\begin{array}{l}\text { There is a positive association between rate of Inflation and } \\
\text { KSE10o. }\end{array}$ & Rejected \\
\hline 3 & $\begin{array}{l}\text { There is a positive link between rate of Interest and stock } \\
\text { market. }\end{array}$ & Rejected \\
\hline 4 & $\begin{array}{l}\text { There is a positive impact of change in prices of gold on the } \\
\text { relationship between rate of inflation and KSE1Oo. }\end{array}$ & Accepted \\
\hline 5 & $\begin{array}{l}\text { There is a positive influence of change in price of gold on the } \\
\text { association between rate of Exchange (Dollar to PKR) and } \\
\text { KSE10o. }\end{array}$ & Accepted \\
\hline 6 & $\begin{array}{l}\text { There is a positive effect of change in prices of Gold on the } \\
\text { connection between rate of Interest and KSE1oo. }\end{array}$ & Accepted \\
\hline
\end{tabular}

Source: Authors' data analysis results, 2021

\subsection{Regression Analysis}

Table 4: Results of t-test and p-test Analysis

\begin{tabular}{|c|c|c|}
\hline Variables & t-Statistics & Probability \\
\hline Constant & 4.591092 & 0.0056 \\
\hline Exchange Rate & 0.198941 & 0.843 \\
\hline Inflation Rate & 0.975786 & 0.3334 \\
\hline Interest Rate & -6.34056 & 0.0040 \\
\hline Gold Price & -1.959667 & 0.0551 \\
\hline
\end{tabular}

Source: Authors' data analysis results, 2021 
Review of Economics and Development Studies, Vol. 7 (3) 2021, 383-394

The t-test is performed to find an evidence of significant difference between population mean and a hypothesized value. The greater value of t-test provide greater evidence against the hypothesis. Table 4 demonstrates that there is solid evidence for significant difference. However, if value of t-test is closer to zero, it shows that there is no significant difference.

P-test is statistical measure that validates the null hypothesis acceptance or rejection claim about population. If value of ' $\mathrm{p}$ ' is smaller, the stronger the evidence that null hypothesis should be rejected while t-test and p-test both value shows the significance of hypothesis.

The value of normal probability should be less than 0.05.As stated in the above table, interest rate has the $t$-value of -6.3406 and $p$-value is 0.000 , rate of inflation has the t-value of 0.9758 and $p$ value is 0.3334 , rate of exchange has the $t$-value of 0.1989 and $p$-value is 0.8430 , gold price has the $t$ value of 1.9597 and $p$-value is 0.0551 . These above stated values explained that interest rate and gold prices was negatively significant, whereas the exchange rate and inflation rate was positively insignificant.

Table 5: Results of Hypothesis

\begin{tabular}{|c|c|c|}
\hline Serial \# & Name of independent variable & Direction of hypothesis \\
\hline 1 & Exchange Rate(Dollar to PKR) & Positive Insignificant \\
\hline 2 & Inflation Rate & Positive Insignificant \\
\hline 3 & Interest Rate & Negative Significant \\
\hline 4 & Gold price & Negative Significant \\
\hline
\end{tabular}

Source: Authors' data analysis results, 2021

Coefficient of correlation was used for hypothesis testing and to check the significant relationship among inflation rate, exchange rate (Dollar to PKR), interest rate, and gold price. Four research hypotheses $\mathrm{H}_{1}, \mathrm{H}_{4}, \mathrm{H}_{5}, \mathrm{H} 6$ out of six hypothesis ( $\left.\mathrm{H}_{1}, \mathrm{H}_{2}, \mathrm{H}_{3}, \mathrm{H}_{4}, \mathrm{H}_{5}, \mathrm{H} 6\right)$ were accepted, whereas two hypothesis $\mathrm{H} 2$ and $\mathrm{H} 3$ were rejected.

Table 5: Results of OLS Multi-Regression Model Analysis

\begin{tabular}{|l|c|c|c|c|}
\hline Variables & Coefficients & Std. Error & t-Statistics & Prob. \\
\hline C & 0.1101 & 0.015005 & 7.337342 & 0.0000 \\
\hline Exchange rate & 1.20218 & 0.373260 & 3.220756 & 0.0018 \\
\hline Inflation rate & -0.93549 & 0.418622 & 2.234689 & 0.0074 \\
\hline Interest Rate & -1.03708 & 0.287950 & 3.601597 & 0.0006 \\
\hline Gold price & -0.4587 & 0.107755 & 4.256841 & 0.0008 \\
\hline \multicolumn{2}{|c|}{ R Squared value } & 0.842214 & Mean dependent variable & 37614.23587 \\
\hline Adjusted R-Squared & 0.616193 & S.D. dependent variable & 6631.8281 \\
\hline \multicolumn{2}{|c|}{ S.E. of regression } & 4108.55847 & Akaike info criterion & 19.55919 \\
\hline Sum squared residual & 9.28408 & \multicolumn{2}{c|}{ Schwarz criterion } & 19.73372 \\
\hline $\begin{array}{c}\text { Log likelihood } \\
\text { F-Statistics }\end{array}$ & -581.77612 & Hannan-Quinn criterion & 19.62746 \\
\hline \multicolumn{2}{|c|}{$\begin{array}{c}\text { Probability(F- } \\
\text { Statistics) }\end{array}$} & 24.68082 & Durbin-Watson statistics & 1.758904 \\
\hline
\end{tabular}

Source: Authors' data analysis results, 2021 


\section{Review of Economics and Development Studies, Vol. 7 (3) 2021, 383-394}

The results of OLS Regression analysis have been summarized in table 6.5. The impact of variability in dependent variable induced due to independent variable is illustrated by the value of $R$ Squared. The results showed that value of $\mathrm{R}$ Squared was 0.6422 and it indicates that an $84.22 \%$ variation in the dependent variables (KSE-100 index) is explained by the selected macroeconomic variables (inflation, exchange, real interest rate and gold prices). The remaining $15.78 \%$ of the variations in the stock index movement is due to other variables not included in the model. DurbinWatson test has value of 1.7589 and this value is under the range of Durbin-Watson statistics of 2; providing the evidence that there is no existence of serial auto-correlation.

\section{Conclusions and Recommendations}

This study examined the impact of most crucial macroeconomic variables i.e. inflation, exchange and real interest rates along with mediating variable of gold prices volatilities on the overall performance of stock market of Pakistan. Six research hypotheses were formulated and out which four hypotheses got accepted while the remaining two were rejected. The study results proved that exchange rate (Dollar to PKR) was positively affecting the performance of KSE10o Index whereas, inflation rate and interest rates were negatively affecting the overall performance of KSE10o index. The study also found that there was positive impact of fluctuations in the price of Gold on the relationship among exchange rate and KSE10o, inflation rate and KSE10o, real interest rate andKSE10o. The value of coefficient for exchange rate was 1.20218 showing positive impact on stock market performance at $1 \%$ significance level. The coefficients of gold prices, inflation and interest rate revealed significant negative impact on performance of stock market. The value of $\mathrm{R}$ squared was 0.6422 which illustrated that $64.22 \%$ variations have been explained by our proposed model and the remaining variation was due other controlled variables not included in this study analysis.

Keeping in view the results of this study, it can be recommended that relatively low interest rate, inflation rate will leads to better performance of the stock market. Furthermore a detailed study in other sectors like energy, oil \& gas, and industrial production index with wider time span may increase generalization capabilities of this study.

\section{References}

Adebowale, E. A., \& Akosile, A. I. (2018). Interest rate, foreign exchange rate, and stock market development in Nigeria. Binus Business Review, 9(3), 247-253.

Alam, Q. N. (2020). Impacts of macroeconomic variables on the stock market returns of South Asian region. Can. J. Bus. Inf. Stud, 2(2), 24-34.

Ali, A., Khan, M. K., \& Ullah, H. (2021). Dynamic impact of Gold Prices, Oil Prices and Exchange Rate on Stock Market Performance: A Case of Pakistan's Stock Exchange (KSE 100 Index). Review of Economics and Development Studies, 7(1), 1-12.

Ali, H. (2014). Impact of Interest Rate on Stock Market; Evidence from Pakistani Market. IOSR Journal of Business and Management, 16(1), 64-69.

Al-Naif, K. L. (2017). The relationship between interest rate and stock market index: Empirical evidence from Arabian countries. Research Journal of Finance and Accounting, 8(4), 181191.

Bhuiyan, E. M., \& Chowdhury, M. (2020). Macroeconomic variables and stock market indices: Asymmetric dynamics in the US and Canada. The Quarterly Review of Economics and Finance, 77, 62-74.

Chandrashekar, R., Sakthivel, P., Sampath, T., \& CHITTEDI, K. R. (2018). Macroeconomic variables and stock prices in emerging economies: A panel analysis. Theoretical \& Applied 
Economics, 25(3).

Elumilade, D. O., Asaolu, T. O., \& Ologunde, A. O. (2006). Capital budgeting and economic development in the third world: the case of Nigeria. International Research Journal of Finance and Economics, 2(2), 136-152.

Engle, R.F. and J.G. Rangel, 2005. The spline GARCH model for unconditional volatility and its global macroeconomic causes.CNB Working Papers Series, 13: 1-28.

Geske, R., \& Roll, R. (1983). The fiscal and monetary linkage between stock returns and inflation. The journal of Finance, 38(1), 1-33.

Gokmenoglu, K. K., \& Fazlollahi, N. (2015). The interactions among gold, oil, and stock market: Evidence from S\&P500. Procedia Economics and Finance, 25, 478-488.

Goodman, B. 1956. The Price of Gold and International Liquidity. Journal of Finance 11, 15-28.

Hashim, S. L., Ramlan, H., Razali, N. H., \& Nordin, N. Z. (2017). Macroeconomic variables affecting the volatility of gold price. Journal of Global Business and Social Entrepreneurship (GBSE), 3(5), 97-106.

Henry, P. B. (2000). Stock market liberalization, economic reform, and emerging market equity prices. The Journal of Finance, 55(2), 529-564.

Hiransha, M., E. A. Gopalakrishnan, Vijay Krishna Menon, and Soman Kp. 2018. NSE stock market prediction using deep-learning models. Procedia Computer Science 132: 1351-62

Hull, J.C., 2012. Options, futures and other derivatives. 8th ed., United States: Prentice Hall.

John, E. I. (2019). Effect of macroeconomic variables on stock market performance in Nigeria. Journal of Economics, Management and Trade, 1-14.

Kakhani, D. G. (2012). Relationship between stock market and foreign exchange market in India: An empirical study. Pacific Business Review International, 5(5), 66-71.

Kumar, K. S. (2011). Study on dynamic relationship among gold price, oil price, exchange rate and stock market returns. International Journal of Applied Business and Economic Research, $9(2), 145^{-165}$.

Pakistan stock exchange market, Government of Pakistan: https://www.psx.com.pk/

Pan, L., \& Mishra, V. (2018). Stock market development and economic growth: Empirical evidence from China. Economic Modelling, 68, 661-673.

Qasim, T. B., Iqbal, G. Z., Hassan, M. U., \& Ali, H. (2021). Application of Markov Regime Switching Autoregressive Model to Gold Prices in Pakistan. Review of Economics and Development Studies, 7(3), 309-323.

Saleem, F., Zafar, L., \& Rafique, B. (2013). Long run relationship between inflation and stock return: evidence from Pakistan. Academic Research International, 4(2), 407-421.

Ullah, G. M. W., Islam, A., Alam, M. S., \& Khan, M. K. (2017). Effect of macroeconomic variables on stock market performance of SAARC countries. Asian Economic and Financial Review, $7(8)$, 770-783. 